\title{
Assessment of psychosocial factors at work: A systematic review
}

\author{
Avaliação de fatores psicossociais no trabalho: \\ uma revisão sistemática
}

\author{
Ana Claudia Souza VAZQUEZ ${ }^{1}$ \\ ORCID iD 0000-0002-7760-9266 \\ Mauricio PIANEZOLLA ${ }^{2}$ \\ ORCID iD 0000-0003-2066-5475 \\ Claudio Simon HUTZ $^{3}$ \\ ORCID iD 0000-0002-3252-7339
}

\begin{abstract}
This paper presents a systematic review of Brazilian and international studies on the assessment of psychosocial factors, published between 2009 and 2015, with emphasis on the analysis of assessment instruments. One of the main interests of this review was to identify, in the published articles, the use of principles of Positive Psychology in the analysis of factors of prevention, promotion and health protection of workers. A total of 5,724 articles were found. Articles that were repeated or not written in Portuguese, English or Spanish were excluded. Thus, after analysis, 410 articles remained. Of these, 69 articles that dealt directly with the evaluation of psychosocial factors at work were selected. Most studies address the pathogenesis of psychosocial factors, but there is increasing number of studies that combine the analyses of pathogenic factors with motivational factors in health promotion and in the study of preserved positive aspects. We found that although the findings indicate an incipient movement concerning some protective factors (social support, creativity, engagement, etc.), there are still few studies in the Positive Psychology approach. We suggest that further studies test integrative theoretical models or stressors and motivational factors to deepen the understanding of the protective factors and positive aspects associated with psychosocial factors at work.
\end{abstract}

Keywords: Psychological assessments; Psychosocial factors; Positive psychology.

\section{Resumo}

Este artigo realiza uma revisão sistemática nos estudos brasileiros e internacionais para a avaliação de fatores psicossociais, entre 2009 e 2015, com ênfase na análise de instrumentos de avaliação. Um dos interesses principais nessa revisão foi

1 Fundação Universidade Federal de Ciências da Saúde de Porto Alegre, Programa de Pós-Graduação em Psicologia e Saúde. R. Sarmento Leite, 245, Sala 208, Centro Histórico, 90050-170, Porto Alegre, RS, Brasil. Correspondência para/Correspondence to: A.C.S. Vazquez. E-mail: <anasv@ufcspa.edu.br>.

2 Psicólogo. Porto Alegre, RS, Brasil.

${ }^{3}$ Universidade Federal do Rio Grande do Sul, Instituto de Psicologia, Departamento de Psicologia do Desenvolvimento e da Personalidade. Porto Alegre, RS, Brasil.

$\mathbf{v} \mathbf{v}$

Como citar este artigo/How to cite this article

Vazquez, A. C. S., Pianezolla, M., \& Hutz, C. S. (2018). Assessment of work psychossocial factors: A systematic rewiew. Estudos de Psicologia (Campinas), 35(1), 5-13. https://doi.org/10.1590/1982-02752018000100002 
identificar a utilização dos princípios da Psicologia Positiva na análise dos fatores de prevenção, promoção e proteção à saúde dos trabalhadores nos artigos investigados. Foram encontrados 5.724 artigos. Foram excluídos trabalhos repetidos e não escritos em português, inglês ou espanhol. Restaram 410 artigos. Destes foram selecionados 69 que tratavam diretamente sobre avaliação dos fatores psicossociais do trabalho. A maioria dos estudos lida com a patogênese dos fatores psicossociais, mas há uma produção crescente combinando análises de fatores patogênicos com fatores motivacionais na promoção da saúde e no estudo de aspectos positivos preservados. Constatou-se que embora os achados indiquem um movimento incipiente de considerar alguns fatores protetivos (suporte social, criatividade, engajamento, etc.), ainda há poucos estudos no enfoque da Psicologia Positiva. Sugere-se que estudos futuros testem modelos teóricos integrativos ou fatores estressores e motivacionais para aprofundar o entendimento dos fatores de proteção e aspectos positivos associados a fatores psicossociais no trabalho.

Palavras-chave: Avaliação psicológica; Fatores psicossociais; Psicologia positiva.

The aim of the present study was to identify the assessment of psychosocial factors at work in the scientific literature by analyzing the measurement instruments and their theoretical framework for the finding of evidence in this field, with an emphasis on Brazilian studies. The interest in this subject is due to the literature discussion about the complexity of this phenomenon. This discussion indicates the importance of verifying integrative theoretical models, testing multiple factors and their combinations in labor practice that lead to an understanding not only of the pathogenic aspects and associated risks of harm, but also of healthy aspects that have the potential to act as protective factors for the workers' health (Lorente, Salanova, Martínez, \& Vera, 2014; Ortiz \& Jaramillo, 2013; Ouweneel, Leblanc, \& Schaufeli, 2013).

The International Labor Organization (ILO) defines, in a general way, psychosocial factors at work as the interaction between work (environment, satisfaction, and conditions of the organization) and the worker's capacities (needs, culture, his/ her situation external to work). In the studies on occupational health and worker health, there are two main lines of analysis on the subject. The first one is on pathogenesis and disease prevention, which studies specific aspects of illness, incidence, and prevalence of psychosocial risks at work, as well as its antecedents and consequents. The second one focuses on salutogenesis, which investigates aspects related to health promotion by considering multiple factors (environmental conditions, ergonomic aspects, etc.), the association among them, and their implications on the quality of work life. On the contributed with studies on the subject by analyzing the protection factors that act in the enhancement of healthy and preserved aspects of workers.

Considering the evidence-based studies that support actions to prevent, promote and protect workers' health, the question we ask in the present research is: what psychosocial factors at work are being evaluated by recent scientific research?

\section{Method}

This paper is part of a larger research that aimed to describe the state of the art of international and Brazilian scientific production on psychosocial factors at work. It is a systematic review by the Preferred Reporting Items for Systematic Reviews and Meta-Analyse technique (PRISMA) that aims to ensure transparency, reproducibility and assertiveness for this type of research (Moher, Liberati, Tetzlaff, \& Altman, 2009). Data collection was carried out in September 2015 in the SciELO, Web of Science, PubMed, PsycInfo (APA) and Scopus portals, using the descriptors "psychosocial factors" and "psychosocial risks" and "psychosocial hazards" and "work", both in English and Portuguese. The identification of articles carried out from 2010 to 2015 and resulted in 5,724 articles. The eligibility criteria used were: (1) complete and accessible scientific articles; (2) a single entry in the database for each article; (3) studies in work or organizational context; (4) texts written in Portuguese, English or Spanish. The final sample was 410 articles on the topic published in scientific journals of great impact (Qualis A and 
journal impact factor greater than 2). Of the 410 articles, the present research selected articles that discussed the assessment of psychosocial factors at work, which resulted in a final sample of 69 articles.

\section{Results}

In general, the publication time of the 69 articles was distributed as follows: ten in 2010; eleven in 2011; seven in 2012; fifteen in 2013; eighteen in 2014; and eight in 2015. The publications are constant throughout the period. However, the data from 2015 should be interpreted with reservation, as the collection occurred in September of the same year. The highest frequency of studies was European $(n=40)$, followed by Asian $(n=12)$, North American $(n=8)$, South American $(n=5)$, Oceania $(n=1)$ and Africa $(n=1)$. Most of the articles were empirical studies that used scales adapted for the assessment of psychosocial factors at work $(n=64)$. The other five studies were about the validity of instruments. In this section, the results will be analyzed according to three main aspects: (1) the definition of the construct 'psychosocial factors at work' in the articles; (2) the theoretical framework that substantiates the evaluation and subsequent interpretations; and (3) findings obtained through instruments for measuring psychosocial factors at work.

\section{Definition of the construct}

It should be noted that only $8.7 \%(n=6)$ of the articles in the sample cite their definition of psychosocial factors at work and all of them are studies on psychometric instruments to assess these factors. When investigating validity, the authors seem to assume there is a consensus about the definition of the construct, since they do not even discuss this question, which is surprising because of the recent relevance attributed to the theme. On the other hand, among the definitions found, all of them apply the notion of psychosocial risk at work as damage and injury to the worker, which may be associated with the premature exit from the labor market (Cox, 1993; Hemingway \& Marmott, 1999). The central focus of the studies, therefore, is the search for negative consequences of work that must be the object of preventive interventions in this context. In these studies, prevention specifically refers to: (a) content, organization and management of work, (b) relationships among workers, (c) the context of the labor market and career, and (d) perceptions of individuals on these aspects that have the potential to harm their mental, social and physical health. The definitions that were identified are described in Table 1.

It is noteworthy that the studies on the adaptation of assessment instruments of the

Table 1

Construct definitions found

\begin{tabular}{|c|c|}
\hline Paper & Psychosocial factor at work \\
\hline $\begin{array}{l}\text { Amponsah-Tawiah, Jain, Leka, } \\
\text { Hollis, \& Cox (2013) }\end{array}$ & $\begin{array}{l}\text { "... psychosocial hazards are defined by the International Labor Organization (ILO) (1986) in terms of } \\
\text { the interactions among job content, work organization and management, and other environmental and } \\
\text { organizational conditions, on the one hand, and the employees' competencies and needs on the other; that } \\
\text { prove to have a hazardous influence over employees' health through their perceptions and experience" (p.76). }\end{array}$ \\
\hline $\begin{array}{l}\text { Ansoleaga, Vézina, \& Montaño } \\
\text { (2014) }\end{array}$ & $\begin{array}{l}\text { "... un aumento de la denominada carga psíquica y mental en el trabajo, que sostenida en el tiempo provo- } \\
\text { cará efectos en la salud mental" (p.108). }\end{array}$ \\
\hline $\begin{array}{l}\text { Bergh, Ringstad, Leka, \& } \\
\text { Zwetsloot (2014) }\end{array}$ & $\begin{array}{l}\text { "Those aspects of work design and the organization and management of work, and their social and } \\
\text { environmental context, that have the potential for causing psychological, social or physical harm" (p.825). }\end{array}$ \\
\hline Canivet et al. (2013) & "... the health-related mechanisms causing a person to prematurely leave the labour market" (p.308). \\
\hline $\begin{array}{l}\text { Garrido-Pinzón, Uribe-Rodriguez, } \\
\text { \& Blanch (2011) }\end{array}$ & $\begin{array}{l}\text { "... los factores psicosociales son condiciones en las que se desenvuelve el individuo cuando se relaciona } \\
\text { con el medio. Sin embargo, estas condiciones se convierten en riesgos cuando tienen la potencialidad de } \\
\text { provocar deterioro para la salud del individuo" (p.29). }\end{array}$ \\
\hline $\begin{array}{l}\text { Law, Dollard, Tuckey, \& } \\
\text { Dormann (2011) }\end{array}$ & $\begin{array}{l}\text { "Work stress results from prolonged exposure to workplace psychosocial hazards - aspects of the work } \\
\text { environment, work design, and organizational management - which potentially cause psychological and } \\
\text { social harm" (p.1782). }\end{array}$ \\
\hline
\end{tabular}


insertion of factors associated with interventions to promote and protect workers' health are not necessarily negative in their own right. This aspect will be detailed in the section on measurement scales, but examples of these factors are social support at work, creativity, well-being, and participation in decisions. The presence of these, of course, does not cause harm. What is considered a distress factor in workers is precisely the lack or inadequacy of these factors.

\section{Theoretical models}

The prevalence of two traditional theoretical models in occupational health $(n=50)$ was evidenced in the present research. Most of the studies (68.1\%) were based on the Job DemandControl (JDC) model (Karasek, 1979) that evaluates three central aspects: (1) job control over work regarding creativity, repetition, freedom, and responsibility in the decision-making process; (2) psychological job demands in relation to rhythm, intensity, self-development, performance, and work teams; and (3) social support from supervisors and work colleagues. This theory brings together two psychosocial factors at work: the decision latitude - refers to what extent individuals have control over their work - and the stressing demands that are related to psychological tensions of exposure to existing risk in the asymmetrical relationship between these demands and decision latitude. The factor that seems to act as protection in this analysis is the participation of workers in daily decision-making, which gives them different levels of control over their work.

Job stress in the JDC is the result of constraints on decision latitude, which causes workers to modulate their action alternatives to meet labor demands. In the combination of high job demands and low decision-making power, the power of the individual that is not transformed into action can also be converted into negative outcomes for worker's mental health. In addition, the model includes the following profiles: "Passive work" (low decision latitude and low demand), 8 "Active work" (high decision latitude and high demand) and "Low Mental Strain at work" (high decision latitude and low demand) (Karasek, 1979). Social support was later added to the theoretical model as a mediator of the relationship between demands and work resources (Johnson \& Hall, 1988). This psychosocial aspect of work is evaluated due to the consensus in the scientific literature that it is an important factor to protect workers' health (Vegchel, Van De Jonge, Söderfeldt, Dormann, \& Schaufeli, 2004).

The Effort-Reward Imbalance (ERI) model was identified in $26 \%$ of the articles. It analyzes the imbalance work-worker through the social exchange theory (Siegrist, 1996). Work is seen as a link between self-regulatory functions (i.e., self-esteem, self-efficacy) and social opportunity structures. In this perspective, the focus of analysis would not be the control over labor activities, but the workers' perception of the rewards received by their labor effort. Rewards are social aspects gained in work practices through social status that generates belonging to a group and opportunities to play important roles in society. Thus, workers seek to control their social position in professional life by entering the job market, in opportunities for growth, recognition, education, job security. In this equation, the labor effort may originate from demands arising from the organization of the work (extrinsic source) or individual motivations of the worker in view of such demands (intrinsic source). The ERI theory, therefore, proposes that work stress is caused by imbalance or little reciprocity between effort and rewards, placing the worker in a continuous state of arousal that can lead to outcomes detrimental to his or her health.

Nevertheless, the analysis proposed by the ERI model sheds light on the personal characteristics and resources of the worker that can also explain the high engagement of some individuals in schemes of high effort-high reward due to professional selfactualization. Within this perspective, it is important to highlight that the study of our sample was based on the Job-Resources and Demands Model, from Positive Psychology, and demonstrated that the role of engagement in work is a motivational and protection factor of workers' health (Schaufeli \& 
Bakker, 2004). In addition, $26 \%$ of the studies ( $n=18$ ) did not mention any model that justified their theoretical and interpretation choices.

\section{Assessment of psychosocial factors at work}

We identified 43 different instruments in our sample. Because 33 of them were cited in only one paper, we will report the most frequent ones, which are: Job-Content Questionnaire (43.5\%); Effort-Reward Imbalance (21.7\%); Copenhagen Psychosocial Questionnaire (COPSOQ) (10.1\%); and Demand-Control-Social Support Questionnaire (DCSQ) (7.2\%). The Job Content Questionnaire (JCQ) is an instrument based on the JDC model that was designed to measure work-specific psychosocial factors. It is a self-administered questionnaire with 49 items, composed of five dimensions and the following factors: (1) Decision latitude: intellectual discernment, decision-making authority, skills underutilization, decision-making authority in the work group, formal authority, and representative influence; (2) Psychological Demands and Mental Burden: general demands, role ambiguity, concentration, mental work breakdown; (3) Social support of peers and supervisors: socialemotional, instrumental, hostility; (4) Physical demands: physical load, isometric load, aerobic load; (5) Work insecurity: general insecurity and obsolescence of skills.

The Job Content Questionnaire was adapted to 23 languages, and Araújo and Karasek (2008) validated the Brazilian version with 1,311 formal and informal workers from Feira de Santana, Bahia. The results are in agreement with European, North American and Japanese studies, with reliability indexes between $\alpha 0.65$ and 0.79 for formal workers and between $\alpha 0.55$ and 0.76 for informal workers. However, some subscales presented an $\alpha$ of 0.19 , which indicates low psychometric quality.

In addition to this research, two Brazilian studies used this instrument. Cardoso, Araújo, Carvalho, Oliveira, and Reis (2011) describe the association between musculoskeletal symptoms and psychosocial factors measured by the JCQ in a sample of 3,197 primary school teachers from public schools in Salvador, Bahia. Their findings indicate that it is possible to explain the incidence of pain in the upper extremities of the body in teachers who experience high demands and low control. Souza, Carvalho, Araújo, and Porto (2010) verified the association between psychosocial factors and common mental disorders in 158 electricians of a Brazilian northeast energy company. The prevalence of disorders was $20.3 \%$, in addition to the relation with the high work wear indicated in the model JDC, when the demands of work are high and work control is low.

A reduced version of $J C Q$, found in our sample, is the DSCQ, which has 17 items to measure job demands, control, and social support. The Brazilian version was adapted by Alves, Chor, Faerstein, Lopes, and Werneck (2004) with 94 professionals. Despite the small sample size and lack of data on its reliability, the DSCQ was applied in two Brazilian papers in our sample. Fantini, Assunção, and Machado (2014) studied the relationship between musculoskeletal symptoms and various factors, including psychosocial factors, in a sample of 5,646 workers from the municipal public sector in Belo Horizonte, grouped according to their complaints of body pain. Their findings highlight that the "Healthy Worker Profile" presented higher scores on control over work and lower perception of stressful demands. Unexpectedly, low scores were found for social support in the entire sample. Silva-Junior and Fischer (2014) investigated the relationship between sick leave and psychosocial factors in a sample of 385 workers from the state of São Paulo. The findings point to the influence of workplace violence on long-term leave.

The Effort-Reward Imbalance Questionnaire (ERIQ) is a self-administered questionnaire that evaluates three factors: effort, reward and overcommitment, a behavior which describes an overdose of worker commitment that causes harm to their health (Siegrist, Li, \& Montano, 2014). The full version of ERIQ has 22 items with a four point Likert response and the reduced version has 16 items. It was adapted to Brazilian context and administered to a sample of 111 workers, which is 
considered insufficient to analyze the psychometric characteristics of the instrument (Chor, Werneck, Faerstein, Alves, \& Rotenberg, 2008). Even so, two national studies administered ERIQ. Silva-Junior and Fischer (2014), who also used the DSQ, and Silva, de Souza, Borges, and Fischer (2010) who evaluated the working conditions associated to quality of life and health in a sample of 696 nursing technicians and nursing assistants from a university hospital in São Paulo. In the findings, the imbalance between effort and reward was associated with negative outcomes, such as body pain, vitality, and mental health.

Finally, the Copenhagen Psychosocial Questionnaire, developed by Kristensen, Hannerz, Horg, \& Borg (2005), is the most recognized instrument by the scientific community because it was designed to compare national and international psychosocial factors at work. According to the authors, it is a multifactorial scale not linked to any specific theory, but it compiles several psychosocial factors that are characterized as relevant to work. There are three versions in the third edition of the instrument (COPSOQ III). The first is the complete scale, with 141 items and 30 distinct factors on task type and product, work content and organization, interpersonal relationships and leadership, and work-individual interface, as well as individual factors such as health, well-being and personality. The second is the average one, with 95 assertions (individual items were removed). And the third is the short version, with 44 items and eight dimensions on labor demands, work organization and content, interpersonal relationships and leadership. There is still no Brazilian version of COPSOQ, but Brazilian researchers are part of the COPSOQ International Network (copsoq-network.org). Psychosocial aspects at work that are preserved and potentiate the worker in the labor context are considered in this instrument as factors of promotion and protection to the health of the workers. However, health and wellness measures are maintained only in the full version, which is different from what the theoretical model of Positive Psychology advocates.

\section{Discussion}

Important scientific advances obtained by the investigation of the psychosocial factors at work and by means of assessment instruments developed and validated for different contexts and theoretical models were observed in the articles researched. However, the results of this systematic review lead to reflections on the recent inclusion of the assessment of health protection factors of workers in comparison to the robust data identified in occupational hazards and their associations with damages and injuries to the worker concerning pathogenesis.

In general, what we identified in the papers researched on the assessment of psychosocial factors at work was the high prevalence of studies on work stressors at the expense of the analysis of motivational and social factors that have the potential to preserve the healthy aspects in this context. In this sense, two theoretical models are almost hegemonic in the understanding of the psychosocial aspects at work and both assume such risk factors with high probability of causing harm to the workers. The psychosocial relationship of people with work is analyzed in JDC and ERI in a similar way, based on the hypothesis of causality of the imminent risk of work to workers' health. Nevertheless, the findings indicate a movement, although still modest, to consider some protective psychosocial factors in the multifactorial analysis, such as social support, creativity, engagement, among others pointed out in the results. The most evident example of assessment in this line is the COPSOQ, which included some aspects of wellbeing and health in the analysis, considering them psychosocial factors at work. Furthermore, the Job-Demand and Resources Model is aligned with this idea as it is based on Positive Psychology and focuses on workers' well-being (Schaufeli \& Bakker, 2004; Vegherl et al., 2004).

In addition to the analysis of social determinants and socioenvironmental conditions that act in the prevention of workers' health, some studies aim to understand the complexity of psychosocial factors at work, identifying those that are protective of workers. To do so, they assess behavioral processes that cause the individual to respond adaptively to adverse situations or to overcome obstacles or harm that could result 
from these events (Luthar, Cicchetti, \& Becker, 2000; Rutter, 1987). In general, four processes are analyzed as protective factors: the reduction of risk of negative impact on people, the identification of aspects that can minimize, the chain of negative reactions, the maintenance or establishment of optimal functioning and positive development even under these circumstances, and the individual openness to the opportunities in adverse situations that contribute to their psychological and social adjustment.

On the other hand, it seems that the combination of multiple factors without a comprehensive model to support it does not guarantee complex interpretations about the psychosocial phenomenon at work. This reflection begins with the definition of the construct 'psychosocial factor at work'. The researched demonstrate that its central idea is of damage or injury to the worker's health. This means, for example, that even if the COPSOQ or other assessment instruments have included factors with a potential to protect workers' health, they will be interpreted by the univocal lens of the risk of injury. This, therefore, limits or ignores their potential role as a motivational factor and the positive development of people in the work context. It is important to clarify at this point in the discussion that we are not considering that there is no risk of harm in the work context or that the studies conducted so far have not produced relevant information for the transformation of adverse conditions at work. Nevertheless, it is important for the advances of the area that we also consider that - as some studies in our sample point out - there are positive and healthy psychosocial factors in work contexts. Psychosocial factors are not just a source of burnout, but also of pleasure and self-realization.

Finally, we highlight the variety of assessment instruments of psychosocial factors in our research, with the prevalence of the four scales identified as the most used by the scientific community. However, in our findings, studies on the adaptation and validation of the Brazilian version of the instruments JCQ, ERI and DCSQ stand out, although they are not reliable due to the size or quality of the sample, as the authors point out (Alves et al., 2004; Chor et al., 2008). To obtain robust scientific advances, the assessment of psychosocial factors at work in Brazil must be able to rely on instruments that have adequate psychometric characteristics.

\section{Final Considerations}

The objective of this systematic review was to analyze the instruments for the assessment of psychosocial factors in Brazilian and international studies from 2009 to 2015. The main contribution of the present study is the identification of prevention, promotion and protection factors to workers' health in the papers researched, particularly the instruments adapted for Brazil. Despite the emerging contribution studies on protective factors in this area in view of the robust findings on the pathogenesis of psychosocial factors at work, we consider that its differentiated approach seems to gain ground in interpretations about workers' health. The findings indicate the scientific movement of combining analyses of known pathogenic stressors with the verification of healthy motivational factors in health promotion and in the study of some positive aspects. In the wake of the recent search for a more integrative theory that treats psychosocial factors at work as a complex phenomenon, it seems that the idea of risk of incidence that encompasses both positive and negative aspects in professional and organizational practice has begun to strengthen. In this sense, Positive Psychology and its theoretical models applied to the work context have much to contribute.

It is suggested that further studies test integrative theoretical models or stressors and motivational psychosocial factors by comparing the positive and negative outcomes in work environments. Such studies will allow an in-depth understanding of the protective factors and positive aspects associated with psychosocial factors at work. They will also shed light on workers' health interventions that focus on health promotion and worker well-being. Finally, strong evidence of validity of the instruments for the assessment of psychosocial factors at work in Brazil is needed. 


\section{Contributors}

All authors participated in all phases of the research article.

\section{References}

Alves, M. G. M., Chor, D., Faerstein, E., Lopes, C. S., \& Werneck, G. L. (2004). Versão resumida da "Job Stress Scale": Adaptação para o português. Revista de Saúde Pública, 38(2),164-171.

Amponsah-Tawiah, K., Jain, A., Leka, S., Hollis, D., \& Cox, T. (2013). Examining psychosocial and physical hazards in the Ghanaian mining industry and their implications for employees' safety experience. Journal of Safety Research, 45, 75-84.

Ansoleaga, E., Vézina, M., \& Montaño, R. (2014). Síntomas depresivos y distrés laboral en trabajadores chilenos: Condiciones diferenciales para hombres y mujeres. Cadernos de Saúde Pública, 30(1), 107-118.

Araújo, T. M., \& Karasek, R. (2008). Validity and reliability of the job content questionnaire in formal and informal jobs in Brazil. Scandinavian Journal of Work, Environment and Health (Supplement 6), 52-59.

Bergh, L. I., Ringstad, A. J., Leka, S., \& Zwetsloot, G. (2014). Psychosocial risks and hydrocarbon leaks: An exploration of their relationship in the Norwegian oil and gas industry. Journal of Cleaner Production, 84, 824-830.

Canivet, C., Choi, B., Karasek, R., Moghaddassi, M., Staland-Nyman, C., \& Östergren, P. (2013). Can high psychological job demands, low decision latitude, and high job strain predict disability pensions? A 12-year follow-up of middle-aged Swedish workers. International Archives of Occupational and Environmental Health, 86(3), 307-319.

Cardoso, J. P., Araújo, T. M., Carvalho, F. M., Oliveira, N. F., \& Reis, E. J. (2011). Aspectos psicossociais do trabalho e dor musculoesquelética em professores. Cadernos de Saúde Pública, 27(8), 1498-1506.

Chor, D., Werneck, G. L., Faerstein, E., Alves, M. G. M., \& Rotenberg, L. (2008). The Brazilian version of the effort-reward imbalance questionnaire to assess job stress. Cadernos de Saúde Pública, 24(1), 219-224.

Cox, T. (1993). Stress research and stress management: Putting theory to work. Sudbury: HSE Books.

Fantini, A. J., Assunção, A. A., \& Machado, A. F. (2014). Dor musculoesquelética e vulnerabilidade ocupacional em trabalhadores do setor público municipal em Belo Horizonte, Brasil. Ciência e Saúde Coletiva, 19(12), 4727-4738.

Garrido-Pinzón, J., Uribe-Rodriguez A. F., \& Blanch, J. M. (2011). Riesgos psicosociales desde la perspectiva de la calidad de vida laboral. Acta Colombiana de Psicología, 14(2), 27-34.

Hemingway, H., \& Marmot, M. (1999). Evidence based cardiology: Psychosocial factors in the aetiology and prognosis of coronary heart disease. Systematic review of prospective cohort studies. British Medical Journal, 318(7196), 1460-1467. https://doi.org/10.1136/ bmj.318.7196.1460

Johnson, J. V., \& Hall, E. M. (1988). Job strain, work place social support, and cardiovascular disease: A cross-sectional study of a random sample of the Swedish working population. American Journal of Public Health, 78(10),1336-1342.

Karasek, R. A. (1979). Job demands, job decision latitude, and mental strain: Implications for job redesign. Administrative Science Quarterly, 24, 285-308.

Kristensen, T. S., Hannerz, H., Horg, A., \& Borg, V. (2005). The Copenhagen Psychosocial Questionnaire: A tool for the assessment and improvement of the psychosocial work environment. Scandinavian Journal of Work, Environment and Health, 31(6), 438-449.

Law, R., Dollard, M. F., Tuckey, M. R., \& Dormann, C. (2011). Psychosocial safety climate as a lead indicator of workplace bullying and harassment, job resources, psychological health and employee engagement. Accident Analysis and Prevention, 43(5), 1782-1793.

Lorente, L., Salanova, M., Martínez, M., \& Vera, M. (2014). How personal resources predict work engagement and self-rated performance among construction workers: A social cognitive perspective. International Journal of Psychology, 49(3), 200-207. https://doi.org/10.1002/ ijop. 12049

Luthar, S. S., Cicchetti, D., \& Becker, B. (2000). The construct of resilience: A critical evaluation and guidelines for future work. Children Development, 71(3), 543-562.

Moher, D., Liberati, A., Tetzlaff, J., Altman, D. G., \& PRISMA Group. (2009). Preferred reporting items for systematic reviews and meta-analyses: the PRISMA statement. Annals of Internal Medicine, 151(4). Retrived September 20, 2016, from http://annals.org

Ortiz, F. A., \& Jaramillo, V. A. (2013). Factores de riesgo psicosocial y compromiso (engagement) con el trabajo en una organización del sector salud de la ciudad de Cali, Colombia. Acta Colombiana de Psicología, 16(1), 43-56.

Ouweneel, E., Leblanc, P., \& Schaufeli, W. B. (2013). Do-it-yourself: An online positive psychological intervention to promote positive emotions, selfefficacy, and engagement at work. Career Development International, 18(2), 173-195. https://doi.org/10.1108/ CDI-10-2012-0102

Rutter, M. (1987). Psychosocial resilience and protective mechanisms. American Journal of Orthopsychiatry, 57(3), 316-331. https://doi.org/10.1111/j.1939-00 25.1987.tb03541.x 
Schaufeli, W. B., \& Bakker, A. B. (2004). Job demands, job resources and their relationship with Burnout and Engagement: A multisample study. Job Organizational Behavior, 25, 309-238.

Siegrist, J. (1996). Adverse health effects of high-effort/ low-reward conditions. Journal of Occupational Health Psychology, 1(1), 27-41.

Siegrist, J., Li, J., \& Montano, D. (2014). Psychometric properties of the effort-reward imbalance questionnaire. Düsseldorf: Düsseldorf University. Retrived September 20, 2016, from https://pdfs.semanticscholar.org/a7f1/ cb357063e76969fe9ca7301cfd978b1f6842.pdf

Silva, A. A., de Souza, J. M., Borges, F. N., \& Fischer, F. M. (2010). Health-related quality of life and working conditions among nursing providers. Revista de Saúde Pública, 44(4), 718-725.
Silva-Junior, J. S., \& Fischer, F. M. (2014). Long-term sickness absence due to mental disorders is associated with individual features and psychosocial work conditions. PLOS ONE, 9(12), e115885.

Souza, S. F., Carvalho, F. M., Araújo, T. M., \& Porto, L. A. (2010). Fatores psicossociais do trabalho e transtornos mentais comuns em eletricitários. Revista de Saúde Pública, 44(4), 710-717.

Vegchel, N., Van De Jonge, J., Söderfeldt, M., Dormann, C., \& Schaufeli, W. B. (2004). Quantitative versus emotional demands among Swedish service employees: Moderating effects of job control and social support. International Journal of Stress Management, 11(1), 21-40. https://doi.org/10.1037/1072-5245.11.1.21

Received: September 29, 2017

Approved: October 25, 2017 